\title{
Genetic Variability of three Natural Populations of Maytenus aquifolium (Celesteraceae) from Telêmaco Borba, Paraná, Brazil
}

\author{
Sandra Aparecida Sahyun ${ }^{1}$, Eduardo Augusto Ruas ${ }^{1}$, Claudete de Fátima Ruas ${ }^{2}$, Cristiano \\ Medri $^{3}$, José Roberto Pinto de Souza ${ }^{1}$, Loana Aparecida Pereira da Silva Johansson ${ }^{4}$, Luíz \\ Vicente Miranda ${ }^{4}$ and Paulo Maurício Ruas ${ }^{2 *}$ \\ ${ }^{I}$ Departamento de Agronomia; ${ }^{2}$ Departamento de Biologia Geral; Universidade Estadual de Londrina; Campus \\ Universitário; C. P. 6001; 86051-970; Londrina - PR - Brasil. ${ }^{3}$ Departamento de Ciências Biológicas e Tecnologia; \\ Fundação Faculdade de Agronomia Luiz Meneghel; BR $369 \mathrm{KM}$ 54, s/n; PR - Brasil. ${ }^{4} \mathrm{KLABIN}$ PPF Não \\ Madeireiros - Fitoterapia; Telêmaco Borba - PR - Brasil
}

\begin{abstract}
Three populations of Maytenus aquifolium from Monte Alegre farm, Telemaco Borba county, Paraná, Brazil were analyzed by RAPD markers. A total of 13 primers were applied wich yielded 283 well amplified markers in all the studied populations (Mortandade, Vila Preta and Trinita), producing different values of gene diversity and polymorphic loci. The analysis of molecular variance (AMOVA) indicated that $21.77 \%$ of the genetic variation was among the population. Pairwise $\mathrm{F}_{\mathrm{ST}}$ analysis showed that the most divergent populations were closer geographically, demonstrating that other factors such as different soil types could explain this variation. Bayesian analysis for $K$ number of clusters and the Principal Coordinate indicated that these three populations were highly structured, corroborating the high values found for the $\mathrm{F}_{\mathrm{ST}}$ and indicating that for conservation purposes all populations should be maintained.
\end{abstract}

Key words: Conservation, genetic diversity, Maytenus aquifolium, RAPD, populations

\section{INTRODUCTION}

Knowledge about the ecology, genetics and botany as well as research on medical, cosmetic and agronomical applications of plants has widely grown (Abadie et al., 2005). Although Brazil has an estimated diversity of fifty thousand species, only a small percentage of all the native plants with pharmacological have properly been studied (Mossi, 2003). The biological diversity which represents wide range of scientific, economic and cultural possibilities depends on the knowledge for management and conservation of natural resources. According to the surveys by Battistelli et al. (2001), Paraná State has a great amount of forest genetic resources, showing natural species with medical properties. This region presents diverse climates due to different altitudes and contributes to the presence of different types of forest formations in this state (Torezan, 2002). Because of the indiscriminate consumption of the plants with medical properties in developing

\footnotetext{
*Author for correspondence: ruas@ sercomtel.com.br
} 
countries and fragmentation of natural ecosystems it is estimated that only $5 \%$ of these plants might be studied before they become extinct (Mossi, 2003). Plants with medicinal properties offer great possibilities of attaining prototype molecules due to the diversity of compounds present in these plants. The interest of the medical community in the usage of the plants for therapeutic purposes is growing as long as their biological activities, efficiency and safety are scientifically proved (Noldin et al., 2003).

Environmental heterogeneities can modify the distribution of genetic variability within or among populations of the same species resulting in genetic differentiation over relatively small geographic distances (Linhart et al., 1981). According to Lowe et al. (2005), fragmentation in neotropical tree species can provoke an increase in disease and infestation by pest and also the establishment of deleterious alleles over shortperiods of time. In long-term, it is expected that this loss of genetic variation would greatly reduce the ability of plant populations to positively respond to different selective pressures. Successful management strategies and the preservation of forest tree species is thus dependent on an accurate assessment of their genetic diversity to address the questions regarding the genetic relationships among individuals as well as the levels and structures of their genetic variation. The knowledge of a particular population genetic structure also provides a historical perspective of the evolutionary changes that characterize a species and allows researchers to more accurately predict how populations of plants will respond to future events of both natural and artificial origin (Wallace, 2002).

The advent of molecular biology techniques involving PCR (Polymerase Chain Reaction) allowed a direct access to the genetic variability contained in the genome of different types of organisms, which made possible to infer the genetic variability within and among the populations of plants. Among the most utilized technique, RAPD (Random Amplified Polymorphic DNA) is a relatively easy and affordable technique and may be employed to any plant species without the necessity of previous knowledge of its genome (Ferreira and Grattapaglia, 1996). An adjustment on the experiments, as well on the statistic analysis guarantees the efficiency of RAPD based markers as source of information for genetic studies in natural populations.

A native of mixed ombrophile forests in Brazil, Maytenus aquifolium (Martius), is an outcrossing shrub that belongs to the Celesteraceae family, grows over six meters in height with a zoochoric dispersion (Perecin, 2000; Scheffer, 2001). It has a wide distribution on the center-western region of Paraná State. Its medicinal potential and scientifically proven efficiency in treating ulcers and gastritis (Mossi, 2003), stimulates indiscriminate usage threatening the survival of this species in its natural habitat (Consema, 2002). The objective of this study was to access the genetic variability of natural populations of Maytenus aquifolium from Monte Alegre farm, Telêmaco Borba County, Paraná for future management and conservation strategies.

\section{MATERIALS AND METHODS}

Plant materials were collected from the natural distinct and well preserved populations from three localities (Mortandade, Latitude-24 ${ }^{\circ} 14^{\prime}$ '901"S, Longitude-50 ${ }^{\circ} 32^{\prime} 920^{\prime \prime} \mathrm{W}$, Altitude- $827 \mathrm{~m}$; Vila Preta, Latitude-24 $06^{\prime}$ '981" S, Longitude-50 22' 037" W, Altitude-808 m; and Trinita, Latitude 24 17'245” S, Longitude - 50.31' 058” W, Altitude-797 m) situated at Monte Alegre farm in the county of Telêmaco Borba, Paraná State, Brazil. For genetic analysis, young leaves of 30 individuals from each population were collected with a minimal distance between plants of five meters.

Genomic DNA was extracted with DNeasy Plant Minikit supplied by Qiagen (Qiagen Ltda., Crawley, West Sussex, UK). The concentration of DNA was estimated using a fluorometer (DyNA Quant 200, Höfer-Pharmacia), in accordance with the manufacturer's instructions. DNA samples obtained were adjusted to $10 \mathrm{ng} / \mu \mathrm{l}$ for PCR use. A total of 13 primers (Operon, Technologies; Table 1) were selected for the analysis. DNA amplifications were performed in a final volume of $15 \mu \mathrm{l}$ containing $1 \mathrm{x}$ PCR buffer $(75 \mathrm{mM}$ Tris$/ \mathrm{HCl}, 50 \mathrm{mM} \mathrm{KCl}, 2.0 \mathrm{mM} \mathrm{MgCl}_{2}$, and $20 \mathrm{mM}$ $\left.\left(\mathrm{Nh}_{4}\right)_{2} \mathrm{SO}_{4}\right) ; 0.2 \mathrm{mM}$ each of dATP, dTTP, dCTP, and dGTP; $0.4 \mu \mathrm{M}$ of each primer; 0.9U Taq DNA polymerase (Biotools-Spain); and 20ng of template DNA. PCR amplifications were carried out using a PTC 200 (MJ Research) thermal cycler using the following conditions: $3 \mathrm{~min}$ at $94^{\circ} \mathrm{C}$ 
followed by 48 cycles of $1 \mathrm{~min}$ at $94^{\circ} \mathrm{C}, 1 \mathrm{~min} 45 \mathrm{~s}$ at $38^{\circ} \mathrm{C}$, and $2 \mathrm{~min}$ at $72^{\circ} \mathrm{C}$. The final cycle was followed by a $7 \mathrm{~min}$ extension step at $72^{\circ} \mathrm{C}$. The samples were then stored at $4^{\circ} \mathrm{C}$ until electrophoresis (Oliveira et al., 2010).

Amplified products were resolved in $1.2 \%$ agarose gels in TAE buffer $(40 \mathrm{mM}$ Tris-acetate, $1 \mathrm{mM}$ EDTA, $\mathrm{pH} 8.0$ ) at $120 \mathrm{~V}$ for $3 \mathrm{~h}$ and stained with ethidium bromide (Diniz et al., 2005). Only the molecular fragments that showed strong amplification pattern were considered. Homology assessments were made across gels based on an amplified GENE Ruler DNA ladder of 100bp (Fermentas AB, Vilnius, Lithuania). Control samples containing all the reaction material, except for the template DNA was also run to ensure that no self- amplification or DNA contamination occurred.

\section{Statistical analysis}

The mean coefficient of variation (CV) based on the assessment of the errors associated with the estimation of the genetic similarity of the 283 RAPD markers was obtained after 1000 bootstrap samples using the Dboot software,version 1.1 (Coelho, 2001). The frequencies of the markers were used to calculate the genetic diversity within population $\left(\mathrm{H}_{\mathrm{S}}\right)$, the total gene diversity $\left(\mathrm{H}_{\mathrm{T}}\right)$ according to Nei (1987) using the software Popgene (Yeh et al. 2000). Variation in RAPD patterns were verified by the analysis of molecular variance (AMOVA) and pairwise $\mathrm{F}_{\mathrm{ST}}$ using the Arlequin software, version 2.0 (Schneider et al. 2000). Principal coordinate analysis was based on Jaccard coefficient using the software FAMD (Schlüter et. al., 2006). An alternative approach using the Bayesian clustering method was also applied to infer the number of possible clusters (K) that were most appropriate to interpret the data (Structure version 2.1, Pritchard et al., 2000).

\section{RESULTS AND DISCUSSION}

To evaluate the genetic variation among the studied populations of M. aquifolium, a total of 13 primers were selected by their repeatability and the number of polymorphic loci on 90 plants evenly distributed among three different subpopulations generating a total of 283 well amplified markers. These markers were submitted to a bootstrap wich yielded a Coefficient of Variation (CV) lower than 5\% (Fig. 1). Hollingworth and Ennos (2004) suggested that low levels of $\mathrm{F}_{\mathrm{ST}}(<0.07)$ could be obtained for natural populations when sufficient number of molecular markers was used. However, in the same natural population, high levels of $\mathrm{F}_{\mathrm{ST}}$ (> 0.15 ) were found when an insufficient number of markers were analyzed, creating a distortion in the $\mathrm{F}_{\mathrm{ST}}$ results.

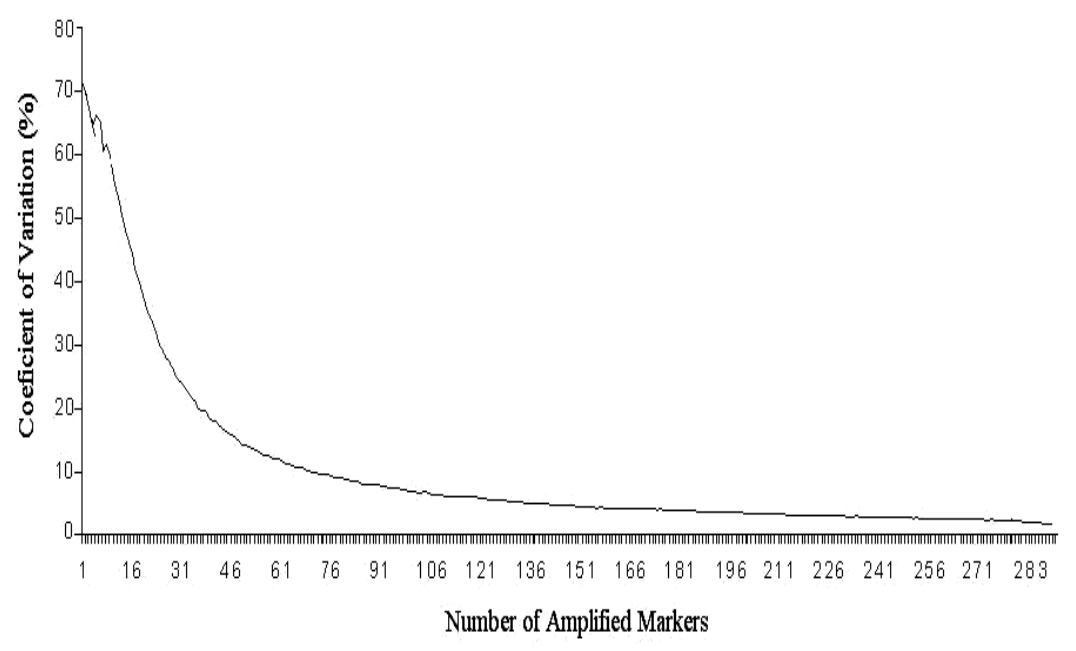

Figure 1 - Coefficient of variation (CV) related to the number of amplified markers, obtained through 1023 permutations. 
For these reason, it was very important in the studies of natural population, like M. aquifolium, to obtain low levels of $\mathrm{CV}$ indicating that a sufficient number of molecular markers were analyzed to describe these population with a high level of reliability.

All the studied populations (Mortandade, Vila Preta and Trinita) of $M$. aquifolium showed different values of gene diversity $(0.211,0.209$ and 0.170$)$ and polymorphic loci $(84.51 \%, 80.57 \%$ and $72.80 \%$ ). The values for the total gene diversity $\left(\mathrm{H}_{\mathrm{T}}=0.224\right)$ and within populations gene diversity $\left(H_{S}=0.197\right)$ (Table 1$)$ were considered to be moderate when compared to results from others outcrossing plants with similar biology using RAPD markers (Lee et al. 2002; Zimback et al. 2004). Using ten isoenzymatic loci, Perecin and
Kageyama (2002) observed a polymorphism between 40 and $70 \%$ in five natural populations of M. aquifolium distributed in the states of São Paulo and Paraná. Similar results were observed by Mossi et al. (2007) in a study of three populations of Maytenus ilicifolium, a species closer to M. aquifolium. The authors observed that $71.5 \%$ of RAPD markers were polymorphic. These results were in agreement with the genetic variability showed by the RAPD markers for the three populations of Telêmaco Borba, Paraná State investigated in the present study. However, in the present study, the level of genetic polymorphism observed in M. aquifolium was higher, suggesting that the populations located in Telêmaco Borba were better conserved.

Table 1 - Gene diversity and percentage of polymorphic loci in populations of A. aquifolium from Telêmaco Borba, Paraná, Brasil.

\begin{tabular}{lccc}
\hline Parameters & Mortandade & Vila Preta & Trinita \\
\hline Gene diversity & 0.211 & 0.209 & 0.170 \\
Number of polymorphic loci & 240 & 228 & 204 \\
Percentage of polimorphyc loci & 84.51 & 80.57 & 72.80 \\
\hline
\end{tabular}

$\mathrm{H}_{\mathrm{T}}$ : total gene diversity. $\mathrm{H}_{\mathrm{S}}$ : gene diversity within populations

Table 2 - Molecular variance analysis (AMOVA) for the three populations of M. aquifolium.

\begin{tabular}{lccc}
\hline Source of variation & DF & $\begin{array}{c}\text { Variance } \\
\text { Components }\end{array}$ & $\begin{array}{c}\text { Percentage } \\
\text { of variation }(\%)\end{array}$ \\
\hline Between populations & 2 & 9.4291 & $21.77 * * *$ \\
Within populations & 87 & 33.8927 & 78.23 \\
Total & 89 & 43.3219 & \\
FST & 0.2177 & & \\
\hline
\end{tabular}

*** $\mathrm{P}<0.001$ with 1023 permutations

The analysis for the molecular variance (AMOVA) was highly significant and indicated that $21.77 \%$ of the genetic variation was among the populations (Table 2) corroborating the results obtained by Hamrick et al. (1992) in outcrossing woody plant species. Pairwise $\mathrm{F}_{\mathrm{ST}}$ analysis (Table 3 ) revealed that the most divergent populations were Mortandade and Trinita $\left(\mathrm{F}_{\mathrm{ST}}=0.2939\right)$ even though they were closer geographically $(6.6 \mathrm{Km})$, demonstrating that no evident relation between geographical and genetic distances could be observed among these populations. Such results could be explained by the different $\mathrm{pH}$ and soil types at each population site as the climate, reproductive biology and richness of polinators were the same for all the three populations. Both, Mortandade and Vila Preta grow in argillaceous soils (pH 3.8 and 4.5, respectively) while Trinita grows in a sand soil ( $\mathrm{pH} 5.0$ ).

Although a high genetic divergence among these populations were observed, no diagnostic markers were found, demonstrating that the high levels of genetic variation found in these populations are related to the distribution of the RAPD marker frequencies in each population. Bayesian analyses demonstrated that the populations of $M$. aquifolium were highly structured. The individuals were grouped according to their origin into three clusters $(K=3)$ with $97 \%$ of probability. These results were confirmed by the Principal Coordinate 
Analysis (PCOA, Fig. 2) that showed the same association. In conclusion, all the three populations should be maintained as they represent a diverse source of genetic variability and could play a key role in the preservation of these species in this region.

Table 3 - Pairwise $\mathrm{F}_{\mathrm{ST}}$ and geographic distance among three populations of M. aquifolium.

\begin{tabular}{lcc}
\hline Interactions & $\mathbf{F}_{\mathbf{S T}}$ & Geographic distance (Km) \\
\hline Mortandade x Vila Preta & $0.1608^{* * *}$ & 23,3 \\
Mortandade x Trinita & $0.2939^{* * * *}$ & 6,6 \\
Vila Preta x Trinita & $0.1919^{* * *}$ & 24,7 \\
\hline$* * * \mathrm{P}<0.001$ with 1023 permutations & &
\end{tabular}

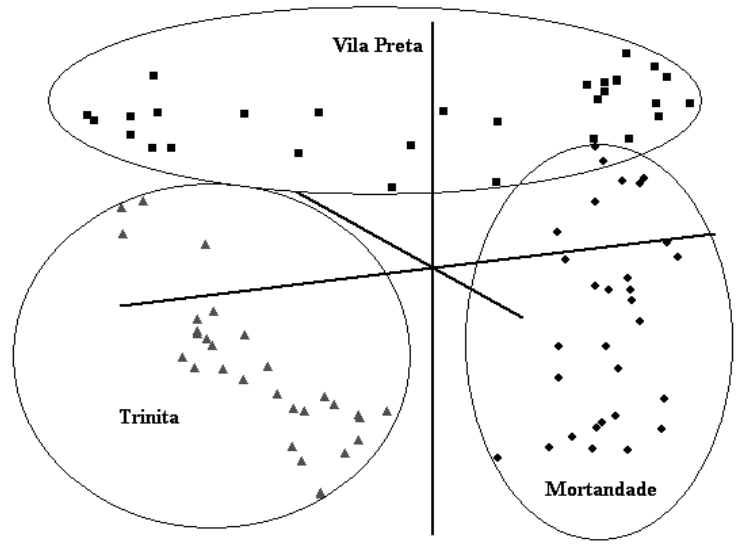

Figure 2 - Principal Coordinate Analysis of three populations of M. aquifolium from Monte Alegre Farm, Telêmaco Borba, Paraná State, Brazil. The first, second and the third principal coordinates explain $18.86 \%, 8.31 \%$, and $7.50 \%$ of the total variation, respectively.

\section{ACKNOWLEDGEMENTS}

We acknowledge to Klabin Florestal for financial support.

\section{RESUMO}

Três populações de Maytenus aquifolium coletadas na fazenda Monte Alegre, localizada no município de Telêmaco Borba, Paraná, Brasil foram analisadas por marcadores de RAPD. Treze primers de RAPD foram amplificados produzindo 283 bandas com alta capacidade de repetição nas três populações estudadas (Mortandade, Trinita e Vila Preta), com as quais valores diferentes de diversidade gênica e locos poplimórficos foram calculados. Análise da variância molecular (AMOVA) mostrou que $21,77 \%$ da variabilidade genética é encontrada entre populações. Análise do Fst entre pares de populações mostrou que as mais divergentes são geograficamente mais próximas, demonstrando que outros fatores tais como tipos distintos de solos podem explicar estas variações. Análise Bayesiana para número $\mathrm{K}$ de clusters e a Análise da Coordenada Principal mostraram que estas três populações estão altamente estruturadas, corroborando os altos valores encontrados para o Fst e indicando que para propósitos de conservação todas as populações devem ser mantidas.

\section{REFERENCES}

Abadie, T.; Cordeiro, C. M.T.; Fonseca, J. R.; Alves, R. B. N.; Burle, M. L.; Brondani, C.; Rangel, P. H. N.; Castro, E. M.; Silva, H. T.; Freire, M S.; Zimmermann, F. J. P. and Magalhães, J. R. (2005), Constructing a rice core collection for Brazil. Pesquisa Agropecuária Brasileira, 40, 129-136 2005. 
Battistelli, D.A.; Pacheco, C.V.; Silva, D. W. Da and Steenbock, W. (2001), Plantas da nossa gente - a sabedoria popular no uso de plantas medicinais. First ed. Guarapuava, Fundação Rureco.

Coelho, A.S.G. (2000), Bood: Avaliação de dendrogramas baseados em estimativas de distâncias/similaridades genéticas através do procedimento de bootstrap. Goiânia,GO. Laboratório. de Genética Vegetal, Departamento de Biologia Geral, Universidade Federal de Goiás.

Comsema, Secretaria do Meio Ambiente do Estado do Rio Grande do Sul: Espécies da Flora Ameaçadas de Extinção do Rio Grande do Sul ANGIOSPERMAE (2002), Disponível em: http://www.sema.rs.gov.br/sema/html/

Diniz, L.E.C.; Ruas, C.F.; Carvalho, V.P.; Torres, F.M.; Ruas, E.A.; Santos, M.O.; Sera, T.; Ruas, P.M. (2005), Genetic diversity among forty coffee varieties assessed by RAPD markers associated with restriction digestion. Brazilian Archives of Biology and Technology, 48, 511521.

Ferreira, M.E. and Grattapaglia, D. (1998), Introdução ao uso de marcadores moleculares em análise genética. 3.ed. Brasília: EMBRAPA-CENARGEM, pp. 220.

Hamrick, J.L.; Godt, M.J. W. and Sherman-Broylers, S. L. (1992), Factors influencing levels of genetic diversity in woody plant species. New Forestry, 6, 95124.

Lee, S.-W.; Ledig, F.T. and Johnson, D.R. (2002), Genetic variation at allozyme and RAPD markers in Pinus longaeva (Pinaceae) of the White Mountains, California. American Journal of Botany, 89, 566-577.

Linhart, Y.B.; Mitton, J.B.; Sturgeon, K.B. and Davis, M.L. (1981), Genetic variation in space and time in a population of Ponderosa pine. Heredity, 46: 407-426.

Lowe, A.J.; Boshier, D.; Wrd, M.; Bacles, C.F.E. and Navarro, C. (2005), Genetic resource impacts of habitat loss and degradation; reconciling empirical evidence and predicted theory for neotropical trees. Heredity, 95: 255-273.

Hollingworth, P.M. and ENNOS, R.A. (2004), Neighbour joining trees, dominant markers and population genetic structure. Heredity, 92, 490-498.

Mossi, A.J. (2003), Variabilidade genética e de compostos voláteis e semi voláteis em Maytenus ilicifolia Mart. ex Reiss. PhD Thesis Universidade Federal de São Carlos.

Mossi, A.J.; Cansian, R.L.; Leontiev-Orlov, O.; Zanin, E.M.; Oliveira, C.H.; Cechet, M.L.; Carvalho, A.Z. and Echeverrigaray, S. (2007), Intra and inter populational genetic variability in Maytenus ilicifolia Mart. ex Reiss. 1861, through RAPD markers. Brazilian Journal of Biology, 67, 957-961.

Nei, M. (1987), Molecular evolutionary genetics. First edition, New York, Columbia University Press, pp512.
Noldin, V.F.; Cechinel, V. Filho; Monache, F. D.; Benassi, J.C.; Christmann , I.L.; Pedrosa, R. C.and Yunes, R. A. (2003), Composição química e atividades biológicas das folhas de Cynara scolymus $\mathrm{L}$. (alcachofra) cultivada no Brasil. Química Nova, 26, 331-334.

Oliveira, L.V.R.; Faria, R.T.; Ruas, C.F.; Ruas, P.M.; Santos, M.O.; Carvalho, V.P. (2010), Genetic analysis of especies in the genus Catacetum (Orquidaceae) using RAPD markers. Brazilian Arquives of Biology and Technology, 53, 375-387.

Perecin, M.B. and Kageyama, P.Y. (2002), Variabilidade isoenzimática em populações naturais de espinheirasanta Maytenus aquifolia Mart. e M. ilicifolia Mart. ex Reiss. e suas implicações para o manejo da conservação. Revista Brasileira de Plantas Medicinais, 4, 80-90.

Perecin, M.B. (2000), Diversidade genética em populações naturais de espécies de espinheira santa Maytenus aquifolia Mart. e Maytenus ilicifolia Mart. ex Reiss (Celastraceae). PhD Thesis, USP/ESALQ - SP.

Pritchard, J.K.; Stephans, M. and Donnelly P. (2000), Inference of population structure using multilocus genotype data. Genetics, 155, 945-959.

Scheffer, M.C. (2001), Sistema de cruzamento e variação genética entre populações e progênies de espinheira santa. PhD Thesis, Universidade Federal do Paraná.

Schlüter, P.M. and Harris, S.A. (2006), Analysis of multilocus fingerprinting data sets containing missing data. Molecular Ecology Notes, 6, 569-572.

Schneider, S.; Roeseli, D. and Excoffier, L., Arlequin version 2000: a software for population genetics data analysis. Geneva: Genetics and Biometry Laboratory, University of Geneva.

Torezan, J.M.D. (2002), Nota sobre a vegetação da bacia do rio Tibagi. In: Medri, M.E.; Bianchini, E; Shibatta, O.A.; Pimenta J.A. (Eds.). A bacia do rio Tibagi. Universidade Estadual de Londrina.

Wallace, L.E (2002), Examining the effects of fragmentation on genetic variation in Platanthera leucophaea (Orchidaceae): inferences from allozyme and random amplified polymorphic DNA markers. Plant Species Biology, 17, 37-49.

Yeh; F.C.; Yang, R.; Boyle, T. J. and Xiyan, J. M. (2000), PopGene 32. Microsof Window-based Freeware for population genetic analysis, version 1.32 Molecular Biology and Biotechnology Centre, University of Alberta, Canada.

Zimback, L.; Mori, E. S.; Kageyama, P.Y.; Veiga, R. F. A. and Mello Junior, J. R. S. (2004), Genetic structure of Trichilla pallida Swartz (Meliaceae) populations by RAPD markers. Scientia Forestalis, 65, 114-119.

Received: October 14, 2008; Revised: March 23, 2009; Accepted: April 13, 2010. 